doi:10.5937/jaes9-1131

Paper number: 9(2011)4, 209, $449-456$

\title{
SMES IN THE REPUBLIC OF SERBIA: THE DEVELOPING CAPACITIES
}

\author{
Dr Dragan Ćoćkalo * \\ University of Novi Sad, Technical faculty "Mihajlo Pupin”, Zrenjanin, Serbia \\ Dr Dejan Đorđević \\ University of Novi Sad, Technical faculty "Mihajlo Pupin”, Zrenjanin, Serbia \\ Dr Zvonko Sajfert \\ University of Novi Sad, Technical faculty "Mihajlo Pupin”, Zrenjanin, Serbia \\ Dr Srđan Bogetić \\ Belgrade Business School, Belgrade, Serbia
}

Small and mid-sized enterprises (SMEs) represent one of the main generators of economic development in every market economy. In the last thirty years the SME sector has been successful all over the world, especially in newly industrialized and transitional countries. The management process in SMEs is specific because their business activities are performed in conditions of insufficient resources. The development of SMEs is one of the crucial developmental priorities in the Republic of Serbia. This paper represents a review and recommendations for further developmenti of the developing capacities of SMEs in the Republic of Serbia.

Key words: SMEs, economy, development, Serbia.

\section{INTRODUCTION}

One of the important trends in the last 15 years has been a decrease in the average size of enterprises. Even at the beginning of the 1990s the strategic significance of the SME sector for the development of the economy and the process of economic flux internationalization was noted. According to Drucker [08], a step ahead from a big company to a mid-sized one which represents the centre of an economy is, in fact, a radical turn in the ruling trend of developed countries. This trend has been dominant in developed countries for more than a century. It is Drucker's belief that in the future it will no longer be desirable to be "big". Achieving successful results will be in direct relation to the size of a company - a mid-sized company will be an imperative. SMEs are of special importance for the successful development of transitional countries. In this regard "market orientation and entrepreneurial orientation are correlated, but distinct constructs. market orientation reflects the degree to which firms' strategic market planning is driven by customer and competitor intelligence. Entrepreneurial orientation reflects the degree to which firms' growth objectives are driven by the identification and exploitation of untapped market opportunities." [01]. The development of the SME sector is of vital significance for privatisation because it facilitates its acceleration - SMEs represent an autochthonous private sector and they enable the development of domestic private capital [06]. Mahajan [16] says: "The state does not create business opportunities. Entrepreneurs are those who create them. Whatever the state does, it must stimulate entrepreneurship. On this exceptionally competitive market the entrepreneur who has better ideas and who knows how to realize them better than the others is important. Entrepreneurship is not the monopoly of the French, Germans, Americans, Chinese or Indians. The Region of the West Balkans is full of entrepreneurs. The problem is in the small size of West Balkan countries. They are faced with a challenge - how to grow further? For further development they should have a global vision, they should turn around and search for opportunities on a global level". The development of the SME sector is a vital priority for our economy. The Serbian Government has adopted the strategy for developing competitiveness and innovations of SMEs for the period 
from 2008-2013. This strategy should contribute to increasing competitiveness and exports, the further strengthening of the innovative capacity of companies, a dynamic increase in employment and more equal regional development [14]

\section{SMES: THE BASIC CHARACTERISTICS}

For many years SMEs have represented the generators of economic development, both in developed and newly developed countries - especially in transitional ones. The development of enterprising initiative enables the formation of autochthonous private capital and the development of the SME sector creates the conditions for faster local development, the strengthening of private property and solutions to certain macroeconomic problems, such as unemployment [11]. SMEs play a significant role in all OECD countries: they represent over $95 \%$ of the total number of all active companies and participate with $60-70 \%$ in total employment [04]. Between $30 \%$ and $60 \%$ of SMEs can be called innovative and $10 \%$ of them are high- technological companies. It is obvious that SMEs represent a segment which considerably determines the development of national economies. The development of SMEs is certainly the fastest and cheapest way to achieve the overall development of national economies. There are several reasons for this: the risk of SMEs business is mostly on the side of entrepreneurs, SMEs are more flexible in comparison with big companies, they are better adjusted to market requirements, they have low business expenses and lower prices for services/products, they offer greater reliability and efficiency, they have greater possibilities for specialization, they introduce innovations faster, they introduce IT more easily and cheaply. The most significant values of SMEs are market and technological flexibility, an innovative approach and their ability to take risks more easily.

\section{THE ROLE AND POSITION OF SMES IN THE REPUBLIC OF SERBIA}

As in other countries which have begun the transitional process, SMEs in the Republic of Serbia have shown a constant growth in the last ten years. According to data from 2000, there were 60,552 active companies in the Republic of Serbia and the majority of them were small companies - 56,993, while mid-sized companies numbered 2,573, and big companies 986 . At the same time, out of the total number of registered companies (50.041) $82.6 \%$ were private and they mostly belonged to the group of SMEs [03]. In 2000, the most favourable financial results were on the side of small companies in which income exceeded expenses by $0.5 \%$, while in midsized and big companies the total income covered $98.4 \%$ or $97.8 \%$ of expenses. Small companies made $33.9 \%$ of the profit and they recorded $16.8 \%$ of the total deficit, in other words, $8.8 \%$ of the whole deficit from the previous and current years. These results were achieved by small companies with $9.3 \%$ participation in the total capital of all domestic companies from the Republic of Serbia and with $22 \%$ participation in the total number of employed persons in Serbian companies. There were 367,367 employed people in 2001, which represents a slight fall in comparison with the previous year. Big companies employed 777,059 people, or $1.4 \%$ more than the previous year. It is also obvious that the number of employed persons in small companies increased to a total of 314,894 (23\%), (compared with 309,710 the year before). However, the number of employees in mid-sized companies decreased. Therefore, in mid-sized companies in 2000 there were $313.303(22.4 \%)$ employees compared with 275,414 or $20.1 \%$ in 2001 [13]. In the last few years the state administration has facilitated the establishment of certain institutional mechanisms for the development of the SME sector and the promotion of entrepreneurship.

1. The Central Agency for the Development of SMEs and Entrepreneurship was established (by the Serbian Government), whose aim is the stimulation of entrepreneurship, the development of an enterprising climate and IT support in the SME sector. This agency works as a consistuent part of the Agency for Regional Development.

2. An independent network of agencies for the development of the SME sector was also organized. The main financier of this activity was EAR together with the local administration.

3. The National Employment Office and Agency for the Development of SMEs worked together on the implementation of the concept of entrepreneurship centres at local level. 
SMEs participate in the total number of companies in the Republic of Serbia with $99.8 \%$, in employment with $65.5 \%$, with $67.6 \%$ in turnover and approximately $36 \%$ in the GNP (Table 1). As regards exports, the SME sector participates with
$50.2 \%$, in imports the percentage is $64 \%$ and in investments in the nonfinancial sector $51.2 \%$. Micro companies are dominant in the SME sector, making up $95.6 \%$ of the total number and employing almost $50 \%$ of all employees [14].

Table 1. The number of companies according to size and employment [05]

\begin{tabular}{||l|c|c|}
\hline \multicolumn{1}{|c|}{ Size } & Number of companies & Number of employees \\
\hline Up to 50 employees & 88.264 & 300.000 \\
\hline Up to 250 employees & 2.218 & 280.000 \\
\hline Over 250 employees & 503 & 420.000 \\
\hline
\end{tabular}

In 2009 the number of SMEs and entrepreneurship companies increased by 9,337 , which is $45 \%$ less than in the previous year. According to data from the Agency for Economic Records, in the first nine months of 2010 the number of newly established companies and shops was only 3,196 bigger than those which closed business in the same period. This drastic fall in the number of potential entrepreneurs who see a chance for new employment in starting a new business points to the considerably more difficult conditions for starting and maintaining a new business and the consequences of the global economic crisis are also a contributing factor. During 2009 the SME sector could use EUR 369 million. About EUR 318.1 million was from public sources. Out of EUR 252.8 million which was available only EUR 50.8 million was used from foreign sources. The main problems in the development of SMEs on the national market are the following [04]:

1. There is no systemic base which could create favourable conditions for the development of the SME sector. The institutions are not connected and the required level of coordination does not exist.

2. Lack of financial means (although they exist). Namely, financial resources for the development of SMEs are distributed selectively and are not available to all companies and entrepreneurs. This is especially related to state bodies which finance the development of SMEs.

3. Realization of financial means - When commercial banks are in question, both domestic and foreign, the procedure of obtaining loans is very long (minimum three months). The issue is even more complex with those state institutions which give financial support to
SMEs - approximately 3-6 months is needed for funds to be approved. Most analysis dealing with the attitudes of entrepreneurs and SME owners show that it is very difficult to obtain loans despite several credit lines which state institutions and a considerable number of commercial banks offer.

4. The current chamber system is bureaucratic and is not coordinated with the needs of SMEs. Moreover, it is mostly oriented towards big state systems in the process of privatization. The chamber system mainly deals with issues of international regional cooperation. It is focused on big companies and fails to support the requirements of the SME sector, especially the private sector. Regional chambers of commerce are somewhat more flexible but this depends exclusively on the given local economic structure.

5. The owners of SMEs and entrepreneurs are not well enough informed. Despite the existence of numerous economic journals and programmes there is no one who deals with the problems of SMEs especially in the sphere of permanent and current information.

6. The majority of SME directors and owners lack the relevant knowledge and skills from the field of management necessary for the successful management of their companies (such as making business plans or investment studies). Although courses and seminars from this field are organized in regional development centres and regional chambers, they are usually too expensive for the owners of small shops and companies.

There are a number of studies dealing with motivation, and intentions - the elements which in- 
fluence enterprising behaviour and starting-up businesses in different ways, in other words, enterprising behaviour of the young and students and self-employment. This trend is expanding, depending on time (historical) and space (geographical) dimensions [06], [05].

\section{POSSIBILITIES FOR IMPROVING THE COMPETITIVENESS OF SMES IN SERBIA}

\section{Competitive capacity of Serbian companies}

According to the Strategy for the Development of Competitiveness and Innovations of SMEs from 2008-2013, the basic pillars of development policy related to SMEs are: encouraging the opening of new companies, improving the management skills of employees, improving financing and taxation, promoting exports and innova- tions, and improving legislation and the business environment. On the other hand, the competitive position of Serbian companies is unfavourable because they have failed to focus on business efforts in their development. According to the global index of competitiveness issued by the World Economic Forum in 2009 Serbia finished in 93rd place out of 133 countries. In one year alone Serbia fell eight places according to the same index. Slovenia, Montenegro, Croatia, Macedonia, Hungary, Romania and Bulgaria are all ahead of Serbia as are countries such as Panama and Kazakhstan. In our region only Bosnia and Herzegovina is behind Serbia, in 109th place. Table 2 presents the review of West Balkan countries according to the global index of competitiveness issued by the World Economic Forum in 2010.

Table 2. Ranking West Balkan countries according to competitiveness in 2010 [11]

\begin{tabular}{||l|c||}
\hline \multicolumn{1}{|c|}{ Country } & Place \\
\hline Slovenia & 45 \\
\hline Montenegro & 48 \\
\hline Croatia & 77 \\
\hline Macedonia & 79 \\
\hline Serbia & 96 \\
\hline BandH & 102 \\
\hline
\end{tabular}

Out of date technology, poor quality, unattractive packaging and high prices are the main reasons for Serbia's poor competitive position. The manufacturing industry is the least competitive, followed by the metal industry and electronics in which there have been no investments in technology for many years. Businessmen are of the opinion that tax and customs relief are necessary in order to increase competitiveness, accompanied by a reduction in state taxes, as well as lower prices of electrical energy, gas and fuel. Increasing the level of technological equipment is of major significance because the average age of machinery in Serbia is 30 years. Compared to other countries in the region it is lagging behind by 12 years. In terms of technology the Serbian economy is 29.5 years behind the EU as determined by a representative sample of 154 small, midsized and big companies in six economic branches with similar production programmes [17]. The research results dealing with the competitive index of Serbian companies show that as regards the competitive capacity of our companies, $47.93 \%$ of those interviewed think that it partially satisfies international requirements, $43.28 \%$ of them think that domestic companies do not satisfy these requirements while only $5.69 \%$ of interviewees consider these conditions competitive enough for the international market. The most important factors which Serbian companies lack concerning the development of competitiveness are presented in the figure 1. When asked about the level of innovations in domestic companies the majority of those interviewed, $60.17 \%$, think that our companies partially satisfy this factor, $30.52 \%$ are of the opinion that our companies are not innovative, while only $6.55 \%$ consider domestic companies innovative. It is their view that the necessary elements for the development of the competitive capacity of our companies are presented in the figure 2.[07] 


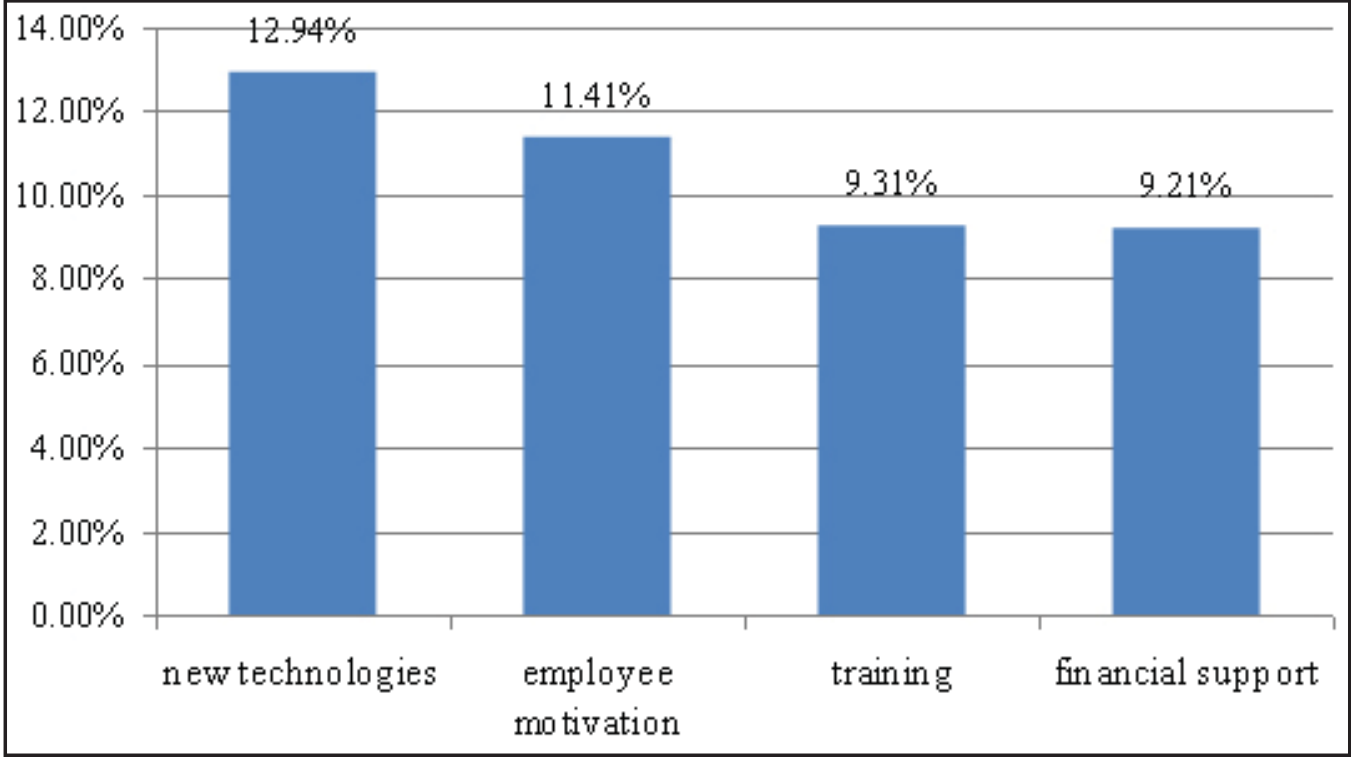

Figure 1. The most important factors which Serbian companies lack concerning the development of competitiveness /13/

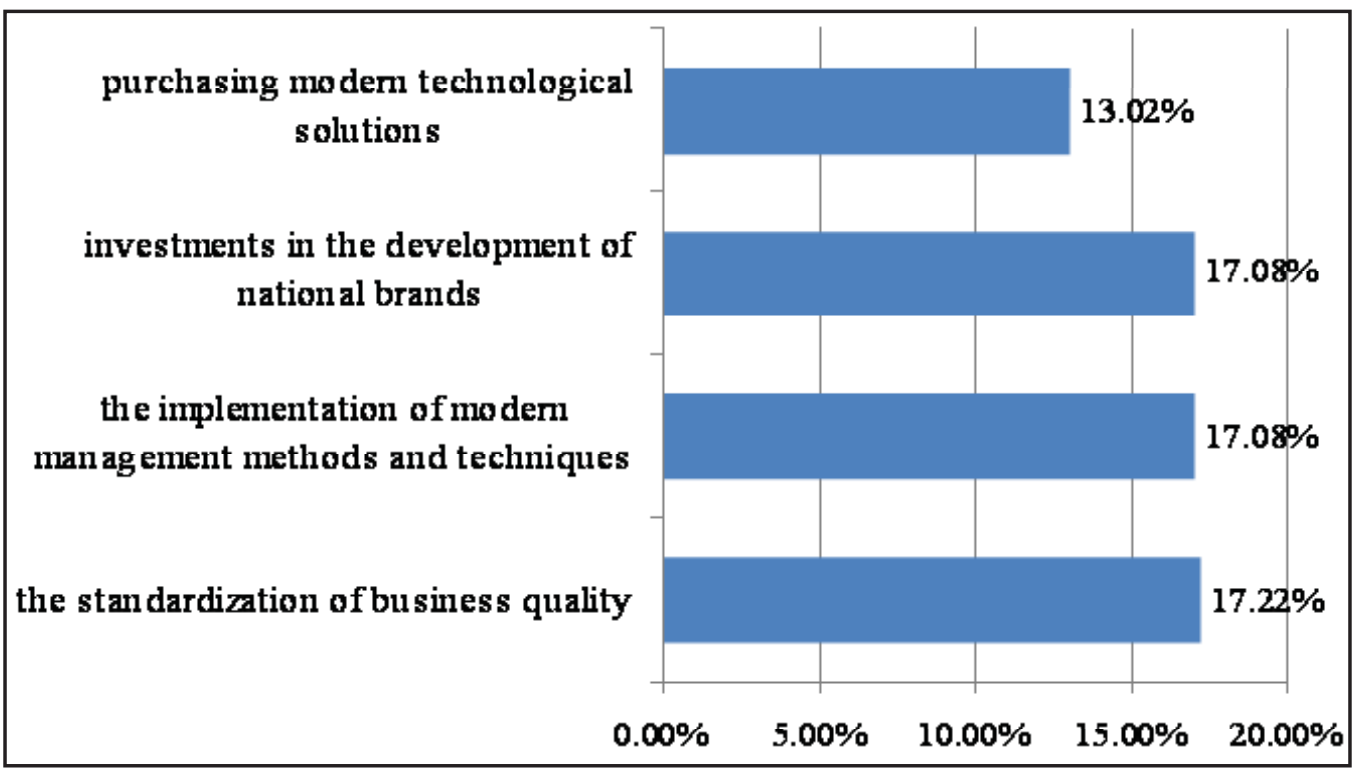

Figure 2. The necessary elements for the development of the competitive capacity of Serbian companies [13]

\section{Forms of improvements in performing business activities in the SME sector}

The principles which should be applied in performing business activities in the SME sector are as follows [11], [12]:

1. A small business does not mean small investments. It only means smaller investments in relation to capacity and the number of employees. A small business means a small number of employees who achieve a high degree of work productivity, the use of mod- ern technology achievements and the realization of development aims (a company's profit and growth).

2. A small business requires the implementation of high technologies but, first of all, it requires knowledge application and the permanent improvement of knowledge productivity.

3. Money does not come easily and quickly. Running a small business requires hard work, competence and diligence from all employees so that productivity of knowledge and work can be achieved. 
4. The market is everything. Getting to know the market, buyers and customers, but competitors as well, establishes the conditions for successful business.

5. The modern market does not tolerate badquality business. Products and services of poor quality cannot be sold on global markets because high technologies are available to all nowadays.

6. The global aim of SMEs is a permanent increase in business productivity. This increase in productivity influences the quality of products which in turn serves to increase productivity. Finally, this results in market expansion and higher employment.

7. Marketing is not advertising. Marketing is not sales. Marketing is a management process which should create the conditions for permanent business performance along with fulfilling a company's development aims.

8. Profit is not the only aim in a modern economy. Profit is a result of well created and realized business. Customer interests and society's welfare are always priorities. Profit comes as a result of satisfied customers who ensure the development of the organization by their loyalty.

9. Small programmes can be stimulated only if they are profitable.

10. Small companies are founded in great numbers but they are also often closed in great numbers because they are not competitive on the market. Not everybody can be successful. Only those firms which can accept the fact that knowledge represents the base of business and increased productivity of work the imperative of modern business will be successful. In addition, such companies should constantly strive to improve quality and satisfy market requirements.

SMEs are leaders in development in relation to innovations and mid-sized organizations are becoming the best options for achieving business success. Reducing the average size of companies creates the necessity for different forms of associations and cooperation between companies which enter the international market - they should achieve a synergic effect. Finally, this assumes the need to form associations and alliances not only for SMEs but for big companies as well. Small and mid-sized enterprises real- ize this through different forms of associations based on common interests, such as agreement on common investment, associations for the realization of innovations, joint appearance on the market, and overcross licensing. Clusters represent one of the significant forms of associating SMEs. The notion of clusters was introduced by the American economist Michael Porter. Clusters represent the geographically limited concentration of similar or complementary businesses with active channels for business transactions, communications and cooperation. Regional clusters represent the concentration of mutually dependent companies in one geographical region. They are limited to one geographical region and consist of a great number of companies and employees within a small number of related industrial sectors. The organization of SMEs is certainly a question of entrepreneurship initiative - entrepreneurs have to find their own interest in associating but they should not be destimulated in the realization of their interests. Although it is up to administrative bodies to establish an institutional framework that will facilitate free entrepreneur associations, the problem of their organization should be the problem of the entrepreneurs themselves. Entrepreneurs should be organized on the basis of private initiative in order to ensure a successful appearance on the market, especially on the international market. These issues are not adequately represented on the Serbian market. According to the Strategy for the Development of Competitiveness and Innovations of SMEs for the period from 2008-2013 clusters are considered as instruments for increasing competitiveness on international markets [14]. Nowadays, there are 22 clusters in the Republic of Serbia, and in 2008, 14 clusters were financially supported by the state - the Ministry for the Economy and Regional Development provided a grant in the amount of RSD 52 million for the start-up and development of clusters (31 million were budget funds and 21 million a donation from Norway) [15]. Four out of 14 clusters were in the process of establishment - the medical tourism cluster, the tourist cluster in Srem, the association for the development of business and manifestation tourism and computers cluster. Only two out of 22 clusters are national - the car industry cluster and the wood industry cluster, while the remaining 19 clusters are regional ones. Clusters are organized as associations of citizens. 


\section{Education for entrepreneurship}

Knowledge is becoming a decisive factor for the development of entrepreneurship in transitional economies. One of the possible options for the improvement of entrepreneurship is the educational process in the field of entrepreneurship. This is related to the training of professionals and company executives, regardless of the ownership type, because of the identical principles of entrepreneurial business. The basic task of this type of education is achieving the knowledge necessary for the successful management of businesses and/or companies so as to increase productivity of work and knowledge. The final aim is business literacy for appropriate business management. Education for entrepreneurship must create the conditions and climate that ensure that newly acquired knowledge can be applied to both work and knowledge (the emphasis is not only on what but also on how something should be done). This means that the total result of education for entrepreneurship should be a manager and an entrepreneur - the generally accepted definition "the one who is responsible for the application and practical use of knowledge" must be applied to him/her. Education for entrepreneurship also includes the following issues: [10]:

1. Acquiring knowledge and the development of creative, problem solving abilities, the development of entrepreneurial style in the population of youth and adults within formal education.

2. Building-up the business management knowledge and abilities of current entrepreneurs and executives (financial and low business, informatics, management, marketing, business communication).

3. Training the unemployed and redundant for the start-up of their own businesses.Special attention must be paid to the implementation of new management approaches, both in a conceptual and organizational sense. Enterprises, including a great number of those organizations which do not belong to enterprises (universities, institutes, etc.), should begin with experiments related to new corporative forms and they should carry out pilot studies especially in cooperation with partners or associations - they should define common tasks, structures and activities.

\section{CONCLUSIONS}

SME-s facilitate the development of an entrepreneurial climate, especially in transitional countries. The main role of entrepreneurship in modern economies is reflected in innovative actions which create the conditions for technological development, flexible organizations and new employment. The development of SMEs and private entrepreneurship in transitional countries serve to boost employment in the whole economy. According to the Strategy for the Development of Competitiveness and Innovations of SMEs for the period from 2008-2013 [14], the economic progress and development of the Republic of Serbia require the development of a competitive economy based on knowledge, new technologies and innovations. Entrepreneurship is expected to make an important contribution to economic and social development. In addition, the readiness of SMEs to enter EU markets, adopt necessary standards and reduce differences concerning the level of development is of special significance. The hope of the global economy is in enabling regions to bring wealth from the rest of the world. In order to accomplish this task regions have to be equipped with highly educated and disciplined people led by visionary leaders able to communicate with the rest of the world [09]. Some of these regions are Hainan island (South China, Guandong Province), Vancouver and British Columbia (Canada), Estonia, Cho Shi Minn (Vietnam), Coastal and Sahalin island (Russia), Sao Paolo (Brazil), and Kiu-shiu (Japan). Serbia has all the preconditions to become one such region in the near future under one condition - our businessmen must change their business philosophy as quickly as possible. Serbia has all the preconditions to become one of these regions in the near future, under one condition - our businessmen must change their business philosophy as quickly as possible. Capital owners and executive management should establish new elements of competitiveness in our companies [02]. Old policies and management techniques must be abandoned in favour of new ones, and we need to learn from the experiences of global leaders and companies from newly industrialized countries which are successful on the global market. Small and mid-sized enterprises can only survive on the global market if they are associated in clusters. However, the state also has a crucial role to play in cluster formation. Cluster 
policy assumes an initiative on the part of the state in the process of their formation, as well as in improving business contacts and relations among associates which is based on commercial and innovation links, knowledge flow and the provision of specialized infrastructural support. Clusters provide SMEs with the following advantages: greater access to new knowledge and skills, common services, partnership support, branding products, the development of marketing strategies, joint work on innovations, more efficient implementation of QMS, and the co-financing of private and state organizations. Economic growth and development of the Republic of Serbia requires the development of such an economy which is competitive and based on knowledge, new technologies and innovations. In order to achieve this objective it is expected from entrepreneurship to give a significant contribution to social and economic development. Besides, it is of special importance the readiness of SME sector to enter and win EU market together with applying necessary standards and reducing differences concerning the level of development.

\section{REFERENCES}

1) Baker, W.A., \& Sinkula, J.M. (2009). "The Complementary Effects of Market Orientation and Entrepreneurial Orientation on Profitability in Small Businesses," in Journal of Small Business Management 47(4), 443-464.

2) Ćockalo, D., Đorđević, D., \& Đurin, S. (2011). Business Strategy of Providing Customer Satisfaction: An Exploratory Study in QM Certified Serbian Companies. Journal of Applied Engineering Science, 9(2), 339-348.

3) Đorđević, D. (2001). Mala i srednja preduzeća [in Serbian]. Belgrade: KAS.

4) Đorđević, D. (2005). "The Situation of SMEs Regarding Financing in Serbia and Montenegro," in International Workshop "Financing of SMEs". Belgrade: Organization of the Black Sea Economic Cooperation, Konrad Adenaure Stiftung Belgrade and Chamber of Commerce of Serbia.

5) Đorđević, D., Bogetić, S., Ćoćkalo, D., \& Bešić, C. (2009) Analiza preduzetničkog ponašanja kod mladih u Republici Srbiji, Megatrend revija, 6(1), 221-234.

6) Đorđević, D., D. Ćoćkalo, \& Bogetić S. (2010). "Preduzetničko ponašanje kod mladih - rezultati istrživanja u Srbiji (The Youth's Enter- prising Behaviour -The Research Results From Serbia)," in Ekonomske teme (Economic Themes) 3/2010, 467-479.

7) Đorđević, D., D. Ćoćkalo, \& Bogetić, S. (2011). "The Role of Knowledge in Improving the Quality of Business within Serbian Companies," in VI International working conference Total Quality Management - Advanced and intelligent approaches. Belgrade: UASQ, 265-270.

8) Drucker,P.(1996). Menadžmentzabudućnost [in Serbian]. Belgrade: PS Grmeč-Privredni pregled.

9) Ohmae, K. (2007). Nova Globalna Pozornica [in Croatian]. Zagreb: Mate.

10) Sajfert, Z., C. Besic, \& Petrovic, N. (2008). "The Role of Corporate Entrepreneurship in the Process of Improving the Quality of the Business of Domestic Companies," [in Serbian] in International convention on quality "Quality for European and World Integrations". Belgrade: UASQ, 259-260.

11) Sajfert, Z., D. Đorđević, \& Bešić, C. (2006). Menadžment Trendovi [in Serbian]. Zrenjanin: Tehnički fakultet "Mihajlo Pupin".

12) Spasojević-Brkić, V., Klarin, M., \& Curović, D. (2009). Dimenzije menadžmenta kvalitetom isporučioca $u$ industrijskim preduzećima Srbije. Istraživanja i projektovanja za privredu, 7(23-24), pp. 67-71.

13) *** (September 2002). "Twenty Percent of the Capital With a Fifty Percent Obtain," [in Serbian] in SME's News. Belgrade.

14) ${ }^{* * *}$ (2008). "Strategy for the Development of SMEs Competitiveness and Innovation for 2008-2013," [in Serbian] in Službeni glasnik RS, br.55/05, 71/05-ispravka, 101/07 i 65/08. Belgrade: Official Gazette RS.

$15)^{* * *}(04.10 .2008)$. "With Clusters in the Hunt For Markets," [in Serbian] in Novac. Belgrade: Ringier.

16) ${ }^{* * *}$ (11.07.2009). "Developing Countries A New Marketing Eldorado," in Novac. Belgrade: Ringier.

17) ${ }^{* * *}$ (16.07.2009). "Serbia Technologically Lags Three Decades Behind EU," [in Serbian] in Blic. Belgrade: Ringier.

18) ${ }^{* * *}$ (2010). "The Global Competitiveness Report 2010-2011," World Economic Forum.

Paper sent to revision: 27.10.2011.

Paper ready for publication: 21.11.2011. 